\title{
A Brief Talk on the Origin and Diachronic Evolution of the Chinese Sentence Pattern "Although p, q"
}

\author{
Xiaoyan Cao \\ School of Literature \\ South China Normal University \\ Guangzhou, China
}

\begin{abstract}
The Chinese sentence pattern "Although $\mathbf{p}, \mathbf{q}$ " is originated from the sentence pattern "though $p, q$ " in the Spring and Autumn Period and the Warring States Period. After long-term development and change, the sentence patterns such as "though $p, q$ ", "although $p, q$ " and "p, but q" have appeared successively. In the late Ming and early Qing dynasties, the Chinese sentence pattern "p, but q" was initially formed. During the Republic of China, this sentence developed into a common sentence.
\end{abstract}

Keywords-transitional complex sentence; "Although p, q"; though; origin; evolution

\section{INTRODUCTION}

Transitional complex sentence is a common type of complicated sentence in Chinese subordinate complex sentence. Its conventional form refers to the form using the transition sign of "though" or "but" type in the conventional situation. The common sentence patterns of transitional complex sentence are "p, but q", "although p, q", "though p, $\mathrm{q}$ " and so on. Among them, the sentence pattern "Although $\mathrm{p}$, q" is the typical form. Conjunctions "though", "but" are often used in pairs in transitional complex sentence with the high frequency, and the main function is to connect the two clauses of the transitional complex sentence to express the grammatical relationship of concession and transition. The conjunction "although" puts forward a certain instance in a concessive manner and the conjunction "but" continues the above, reversing or supplementing the meaning of the previous clause.

At present, the research result of the Chinese sentence pattern "although $\mathrm{p}, \mathrm{q}$ " is mainly the paper "origin and development of transitional conjunction "although $\mathrm{p}, \mathrm{q}$ " of Yu Huili (2006). Yu Wen puts forward his own viewpoint on the time when the conjunctions "although" and "but" appear for the first time, and the origin and formation of conjunction words "although p, q", holding that the conjunction "though" came into being during the period of the Six Dynasties and "but" came into being as the transitional conjunction in the Song Dynasty. "Although" is the origin of the structure "Although p, q", and the transitional conjunction "Although p, q" came into being in modern times of the Ming and Qing Dynasties. To be exact, it first appeared in the Qing Dynasty in The Scholars. However, there is no final conclusion as to when the conjunction "though" and "but" first appeared. On the question of when the conjunction "though" first appeared there are mainly eight different viewpoints: Yang Bojun (1981) believes that it first appeared in the Eastern Han Dynasty; Chu Yong'an (1986) believes that it first appeared in the Six Dynasties; Wang Li (1989) believes that it first appeared in the era of "A Dream of Red Mansions"; Ota Chenfu (2003) believes that it first appeared in the Tang Dynasty; Wu Kaifeng (2006) believes that it first appeared in the Eastern Jin Dynasty; Liu Baishun (2008) believes that it first appeared in the Northern and Southern Dynasties after the Han Dynasty; Xu Chaohong and Jiang Jichang (2010) believe that it first appeared in the Middle Chinese period; $\mathrm{Li}$ Yongchun and Liu Guang (2012) believe that it first appeared in the Western Han Dynasty. On the question of when the conjunction "but" first appeared, there are mainly three different views: Yu Huili (2006) believes that it first appeared in the Song Dynasty; Ding Ye (2010) believes that it first appeared in the late Tang Dynasty; Li Honglin (2015) believes that it first appeared in the Tang and Song Dynasties. This paper won't make in-depth exploration on the problem of when the conjunction "though" and "but" appear for the first time. On the basis of previous studies, the author puts forward different views on two issues: First, the origin of Chinese sentence "Although p, q". Second, the diachronic evolution of the Chinese sentence pattern "Although p, q".

Most of the corpus in the paper come from the language center of Peking University (CCL corpus), and some come from other literature.

\section{The ORIGIN OF THE CHINESE SENTENCE "Although $\mathrm{P}, \mathrm{Q} "$}

Yu Huili (2006) believes that before the Ming and Qing dynasties, there is no structure "although $\mathrm{p}, \mathrm{q}$ " in document literature, and only the conjunction "although" appeared. Therefore, it can be said that "although" is the origin of the structure "although p, q". However, after searching and analyzing, the author thinks that this view of Yu Huili still remains to be discussed.

We know that before the formation of the Chinese sentence pattern "Although p, q", other forms of the sentence pattern expressing "turning meaning" appeared in ancient Chinese. 
In the Spring and Autumn Period and the Warring States Period, the sentence patterns such as "although p, q", "though $\mathrm{p}, \mathrm{q}$ ", and "p, but q" appeared. In the sentence "Although p, q", "Although" is a conjunction referring to the meaning "although" and "even". The former clause connected by the concessive conjunction "though" often shows the factual concession or hypothetic concession, while the latter clause often has no obvious transition conjunction, and the transition meaning is implied between the former clause and the latter clause. For example:

(1) Not because hungry or thirsty, but I can meet the virtuous lady. Although we don't have many friends, the banquet is happy. (The Book of Songs Xiaoya)

(2) Confucius said, "Zang Wuzhong asked Lu Jun to establish his descendants for Zang in the State of Lu. Although some people said that he was not blackmailing the monarch, I do not believe" "(The Analects of Confucius, Question No. 14)

(3) My words have been said, so how can I stint my life for practicing my words? Even if I must die, how can I escape? (Guoyu Jin dialect)

If she is about to marry to a big country, even the king's daughter will be escorted by the officials with high rank. If she is about to marry to the emperor, all the ministers will go to escort, and the monarch does not personally escort. If she is about to marry to a small country, she will be escorted by senior officials. (The Commentary of Zuo Henggong)

In (1) and (2), the word "although" means "although", representing factual concessions. In examples (3) and (4), the word "although" means "even", which is a hypothetic concession. In the above sentence pattern "although p, q", "although" are conjunctions, and the grammatical relationship between the two clauses is concession and transition. In "though $\mathrm{p}, \mathrm{q}$ " sentence, the most common is "although, q" sentence. At this point, "Although" is composed of two words: the conjunction "although" and the pronoun "so", referring to the meaning "though so" and "even so (so)". "Although" is often used at the beginning of the sentence, leading an independent sentence and expressing concession, which is often separated with the latter sentence by a comma. There is no obvious turning conjunction in the latter sentence, but it implies the meaning of transition.

To sum up, the sentence pattern of "p, q" has appeared in The Book of Songs at the earliest. "Although" is a conjunction, which connects the former sentence to express the factual concession or hypothesis concession, and there is no obvious transition conjunction between the latter sentence and the former sentence, but it implies the transition meaning. Moreover, it appeared earlier than "though p, q" sentence. Therefore, the author believes that "although" is not the origin of structure "Although $\mathrm{p}, \mathrm{q}$ ", but the structure "though $\mathrm{p}$, q" appeared early in The Book of Songs is the origin of the sentence structure "Although p, q".

\section{Diachronic EVolution of THE Chinese Sentence PATTERN "Although P, Q"}

Yu Huili (2006) believes that the transition conjunction "although ... but" structure generated in the Qing Dynasty in The Scholars. However, after searching and analyzing, the author thinks that the Chinese sentence pattern of "Although $\mathrm{p}$, q" was first found in The Marriage Stories to Awaken Men: "Although brothers Xue Rubian is serious, can we refuse him burning paper for his mother?" There are two reasons: First, the words "although" and "but" in this sentence are conjunctions, and the connected clauses form a grammatical relationship of concession and transition, which belongs to the category of Chinese transitional complex sentence. Secondly, although there is no final conclusion on the completion time of the book The Marriage Stories to Awaken Men, Yuan Xingpei's The History of Chinese Literature (second edition) believes that the author of the novel is a scholar in the late Ming Dynasty and early Qing Dynasty, and the novel was completed in the Shunzhi period of the early Qing Dynasty. In the CCL corpus, the completion time of The Marriage Stories to Awaken Men is marked as Ming Dynasty. Therefore, it can be assumed that "The Marriage Stories to Awaken Men" was written in the late Ming and early Qing dynasties. As for the completion time of The Scholars, the academic circles mainly believe that it is the period of Qianlong. Yuan Xingpei's The History of Chinese Literature (the second edition) believes that The Scholars was written after the author moved to Nanjing and was almost finished at the age of 49 in the fourteenth year of Qianlong (1749). In CCL corpus, the completion time of The History of Scholars is marked as Qing Dynasty. Therefore, according to the viewpoint of current academic circle, The Marriage Stories to Awaken Men was written earlier than The Scholars. Therefore, based on the above two points, it can be assumed that the Chinese sentence pattern "Although p, q" didn't first appear in "The Scholars", but in "The Marriage Stories to Awaken Men". Then, how did the sentence pattern of "Although $\mathrm{p}, \mathrm{q}$ " develop into the typical pattern of transitional complex sentence in modern Chinese step by step after it came into being for the first time in The Marriage Stories to Awaken Men?

Chinese sentence pattern "Although p, q" has experienced a long evolution process, which mainly can be divided into two periods: the formation period and the development period.

\section{A. Formation Period}

The author finds only one example of the sentence pattern "Although p, q" in The Marriage Stories to Awaken Men. However, this sentence can also be seen in other documents of the same period. For example:

(5) Although he does not know the words, he know where he should use a brush-pen dipped in red ink and where he should use an ink pen and the various types of zi, yi, cheng and zha. (Chapter 100 of Bizarre Happenings Eyewitnessed Over Two Decades)

(6) Although the master can't be compared with the rich merchants, he must be careful. (Chapter 34 of The Scholars) 
(7) Shouyong says: "The reason may be so, but wrong Miss." (Chapter 8 of "Call the Generals)

(8) Master Zhuang said, "You have got the things, but that 150 yuan is still unsecured." (Chapter 16 of Revealing Original State of Officialdom)

(9) Although Boji can use abacus skillfully, there are always some discounts for each account. Is it enough to spend the expenses of a day and a half? (Chapter 31 of A Brief History of Enlightenment)
(10) Di Lei said: "It is true, but there are so many troops, and we do not know where Marshal Yue is. Where should we attack?" (Chapter 58 of The Complete Story of Yue Fei)

In order to fully explain the use of the Chinese sentence pattern "Although p, q" from late Ming Dynasty to the late Qing Dynasty, we took the fifteen ancient books around this time as an example:

TABle I. The Use of Chinese Sentence "Although P, Q" From late Ming Dynasty to the Late Qing Dynasty

\begin{tabular}{|c|c|c|c|c|c|c|c|}
\hline period & the title of books & $\begin{array}{c}\text { though } \\
\text { p, q }\end{array}$ & $\begin{array}{c}\text { even though } \\
\mathbf{p}, \mathbf{q}\end{array}$ & $\begin{array}{c}\text { p, but } \\
\text { q }\end{array}$ & $\begin{array}{c}\text { though } \\
\text { p, only q }\end{array}$ & $\begin{array}{c}\text { notwithstanding } \\
\text { p, q }\end{array}$ & $\begin{array}{c}\text { Although } \\
\text { p, q }\end{array}$ \\
\hline \multirow{5}{*}{$\begin{array}{l}\text { Late Ming and } \\
\text { Early Qing } \\
\text { Dynasties } \\
(\mathbf{1 5 7 3 - 1 6 6 2 )}\end{array}$} & Records of the States in the Eastern Zhou Dynasty & 5 & 5 & 8 & 0 & 0 & 0 \\
\hline & The Marriage Stories to Awaken Men & 6 & 0 & 2 & 3 & 2 & 1 \\
\hline & The Fortunate Union & 6 & 3 & 3 & 0 & 0 & 0 \\
\hline & Flat Mountain and Cold Swallow & 5 & 2 & 11 & 0 & 0 & 0 \\
\hline & Jade Charming Pear & 4 & 3 & 6 & 0 & 0 & 0 \\
\hline \multirow{5}{*}{$\begin{array}{c}\text { Middle Qing } \\
\text { Dynasty } \\
(1662-1840)\end{array}$} & The Scholars & 3 & 0 & 3 & 0 & 0 & 3 \\
\hline & A Dream in Red Mansions & 16 & 4 & 8 & 3 & 3 & 0 \\
\hline & The Wizard of Oz & 1 & 0 & 6 & 0 & 0 & 0 \\
\hline & The Marriage of Flowers in the Mirror & 89 & 0 & 5 & 0 & 0 & 0 \\
\hline & Strange Stories from a Scholar's Studio & 4 & 0 & 0 & 0 & 0 & 0 \\
\hline \multirow{5}{*}{$\begin{array}{c}\text { Late Qing } \\
\text { Dynasty } \\
(1840-1911)\end{array}$} & Revealing Original State of Officialdom & 5 & 0 & 19 & 0 & 9 & 17 \\
\hline & $\begin{array}{llll}\text { Bizarre Happenings } & \text { Eyewitnessed } & \text { Over Two } \\
\text { Decades }\end{array}$ & 0 & 0 & 35 & 0 & 3 & 9 \\
\hline & Nine tails fish & 3 & 0 & 239 & 3 & 3 & 35 \\
\hline & The Travels of Lao Ts'an & 0 & 0 & 4 & 0 & 0 & 0 \\
\hline & A torn lily & 4 & 4 & 9 & 0 & 1 & 0 \\
\hline & subtotal & 151 & 21 & 358 & 9 & 21 & 65 \\
\hline
\end{tabular}

In "Table 1", late Ming Dynasty refers to the period from Wanli year in 1573 to the end of Chongzhen year in 1662 , the early Qing Dynasty refers to the period from 1644 to the unification of the whole country in 1662, the middle Qing Dynasty refers to the period from the unification of the whole country in 1662 to the outbreak of the Opium War in 1840, and the late Qing Dynasty refers to the outbreak of the Opium War in 1840 to the outbreak of the Revolution of 1911.)

From "Table 1", we can see that from late Ming Dynasty to late Qing Dynasty, the use of "Although p, q" sentence is gradually increasing. At the same time, the sentence patterns of "p, but q" and "though p, q" show a strong trend of development, while the sentence patterns of "even though $p$, q", "p, but only q" and "notwithstanding p, q" show a relatively weak trend of development. Therefore, the late Ming to early Qing is the formation period of the Chinese sentence pattern "Although p, q".

\section{B. Development Period}

During the period of the Republic of China, the Chinese sentence pattern "Although $\mathrm{p}, \mathrm{q}$ " developed to a great extent and became a common sentence pattern. For example:

(11) Although the two men started at the same time, they later put Chen Sheng in the main. (Chapter 11 of The Unofficial History of the Qin Dynasty)
(12) Although $\mathrm{Yu}$ and Zhao did not fight for much time, they were already sweaty and panting after being fought by these young men. (Chapter 58 of Twelve Deadly Coins)

(13) Bai Jiangdan, though is also a reactionary gang, but gentlemen somewhat disgusted with gamblers or men of unknown origin. (The Gold Rush five)

Although there is a corridor in the middle, thin plank wall can easily channel sound. (Cold Nights)

In order to fully explain the use of the Chinese sentence pattern "Although p, q" during the Republic of China, we took the fifteen books before and after this period as examples.

In "Table II", the period of Republic of China refers to the period from the founding of the Republic of China in 1912 to the founding of the People's Republic of China in 1949. 
TABle II. The Use of the Chinese Sentence Pattern "Although P, Q" DuRing the Republic of China

\begin{tabular}{|c|c|c|c|c|c|c|}
\hline The title of books & though $\mathbf{p}, \mathbf{q}$ & even though $p, q$ & p, but q & though p, only q & notwithstanding $\mathbf{p}, \mathbf{q}$ & Although $\mathbf{p}, \mathbf{q}$ \\
\hline The informal history of Shunmei & 1 & 0 & 28 & 1 & 20 & 28 \\
\hline Guangling tide & 11 & 2 & 29 & 6 & 8 & 3 \\
\hline Hesitation & 0 & 0 & 9 & 0 & 0 & 2 \\
\hline The philosophy of old Zhang & 0 & 0 & 0 & 0 & 0 & 0 \\
\hline Scream & 1 & 0 & 16 & 1 & 0 & 0 \\
\hline Family & 0 & 0 & 4 & 0 & 0 & 66 \\
\hline Midnight & 0 & 0 & 15 & 0 & 0 & 3 \\
\hline Tales of Hulan River & 1 & 0 & 0 & 0 & 0 & 16 \\
\hline The mortal wind & 15 & 0 & 0 & 0 & 6 & 12 \\
\hline Rickshaw Boy & 0 & 0 & 1 & 0 & 2 & 5 \\
\hline family heirloom & 0 & 0 & 1 & 0 & 0 & 0 \\
\hline Fortress Besieged & 0 & 0 & 1 & 0 & 0 & 0 \\
\hline The tragedy of a woman & 0 & 0 & 1 & 0 & 0 & 0 \\
\hline Hurricane & 0 & 0 & 1 & 0 & 0 & 0 \\
\hline the Sun Shines over the Sanggan River & 0 & 0 & 13 & 0 & 0 & 0 \\
\hline subtotal & 32 & 2 & 119 & 8 & 36 & 135 \\
\hline
\end{tabular}

It can be seen from "Table II" that during the Republic of China, the use of the sentence pattern "Although p, q" was obviously increased, so this period is the development period of the sentence pattern. At the same time, the use of "p, but q", but only q", "though p, q", and "even though p, q" is decreasing compared with the previous period, and the use of "notwithstanding p, q" is increasing compared with the previous period, but the frequency of the use of these sentences is not as good as that of "Although p, q".

To sum up, it is the first time that the Chinese sentence pattern of "Although p, q" appears in The Marriage Stories to Awaken Men. During the late Ming and early Qing dynasties, this sentence structure initially formed. In the period of the Republic of China, this sentence pattern obtained the very large degree development, and became one kind of common sentence pattern.

\section{CONCLUSION}

The author puts forward different views on the origin and evolution of the Chinese sentence pattern of "Although p, q": first, during the Spring and Autumn and Warring States periods, "though $\mathrm{p}, \mathrm{q}$ " was the origin of the sentence pattern of "Although p, q" in Chinese. Second, it is the first time that the Chinese sentence pattern of "Although p, q" appears in The Marriage Stories to Awaken Men. During the late Ming and early Qing dynasties, this sentence structure initially formed. In the period of the Republic of China, this sentence pattern obtained the very large degree development, and became one kind of common sentence pattern.

\section{REFERENCES}

[1] Chu Yong'an. Classical Chinese compound function words [M]. Beijing: China Renmin University Press, 1986. 楚永安.文言复式虚 词[M].北京:中国人民大学出版社, 1986 年.

[2] Lu Shuxiang. 800 words in Modern Chinese[M]. Beijing: Commercial Press, 1999. 吕叔湘.现代汉语八百词 [M]. 北京:商务印 书馆,1999 年.

[3] Liu Jian, Jiang Lansheng, Bai Weiguo, Cao Guangshun. Research on Modern Chinese Functional Words $[\mathrm{M}]$. Beijing: Language Publishing House, 1992. 刘坚,江蓝生,白维国,曹广顺.近代汉语虚词 研究[M].北京:语文出版社,1992 年.
[4] Wang Li. History of Chinese grammar [M]. Beijing: Commercial Press, 1989. 王力.汉语语法史[M].北京:商务印书馆, 1989 年.

[5] Xing Fuyi. A Study of Chinese Complex Sentences [M]. Beijing: Commercial Press, 2001. 邢福义.汉语复句研究[M].北京:商务印书 馆, 2001 年.

[6] Yao Shuangyun. A Study on the Collocation of Relational Marks in Complex Sentences $[\mathrm{M}]$. Wuhan: Central China Normal University Press, 2008. 姚双云.复句关系标记的搭配研究 $[M]$.武汉:华中师范 大学出版社,2008 年.

[7] Yu Huili. The Origin and Development of the Conjunctive "Although ..., but..." [D]. Wuhan: Hubei University, 2006. 俞会利. 转折连词 “虽然……但是……” 的起源及其发展变化[D].武汉.湖 北大学硕士学位论文,2006 年. 